\title{
The Observation of Frog Species at State University of Malang as a Preliminary Effort on Frog Conservation
}

\author{
Dian Ratri Wulandari, Muhammad Habibi Ibrohim, Dwi Listyorini*
}

Biology Department, Faculty of Mathematics and Science, State University of Malang, Malang, Indonesia

\begin{abstract}
Frog is an amphibian which is widely spread around the world. Indonesia houses 450 species which represent $11 \%$ of frog species in the world. In Java Island alone, there live 42 species of frogs and toads. Frogs can be used as an environment indicator in that the presence of frog in a particular place indicates that the place stays natural and unpolluted. The $1^{\text {st }}$ Campus of State University of Malang, which is located in the heart of Malang District, has been developing rapidly currently. Thus, it requires the construction of new various facilities to support its huge activities. Extensive construction can be destructive even damaging to the habitat of frog, which potentially threats the frog's life, if it does not take the environmental impact into careful consideration. This study is aimed to identify the species of frog which survives at State University of Malang with, particularly the frog species found in 1995. Species identification was conducted by observing the morphological character. This study found that there were four species with three species remained survived in 1995; those were Duttaphrynus melanostictus, Polypedates leucomystax, and Kaloula baleta; and one new species called Rana chalconota. This study also revealed that there were four species which were extinct; those were Fejervarya cancrivora, Fejervarya limnocharis, Ingerophrynus biporcatus, and Occidoziga lima. This situation shows the decreasing amount of species from 7 to 4 within the last 17 years. This result indicates that there is a serious environmental degradation which causes the losing of frog habitats. Further research is needed to study the ecological condition changing in order to save the frog species.
\end{abstract}

Keywords: conservation, frog observation, habitat dectruction

\section{INTRODUCTION}

Frog is an amphibian which is widely spread around the world. Frog and toads inhabit in every continent, except Antarctica. Frogs are more abundant in warm, wet tropical areas, but few species are able to adapt with dry and cool climates [1]. Indonesia houses 450 species which represents about eleven percent of the total global anuran species (4100 species). In Java Island alone, there live 42 species of frogs and toads [2]. Frogs are valuable components of aquatic ecosystem as both predators and prey [1, 2, 3]. Frogs have large appetites and help to control insect pest populations. The loss of frogs from an ecosystem would be a missing link that could not be likely replaced by any other species [1]. Small frogs have been successfully reared in captivity for scientific and medical research $[1,2$, 3].

*Corresponding author: Dwi Listyorini

Biology Department, Faculty of Mathematics and Science,

State University of Malang, Malang, Indonesia

Email: listyorini.alj@bio.um.ac.id
Frogs are excellent indicator species $[1,4,5]$. Habitat loss and fragmentation are major threats to frog population because of their most and permeable skin which is sensitive to numerous pollutants, and of its complex life cycle. Most scientists agree that there is a worldwide decline in frog numbers $[1,4,5,6,7]$. Since frogs need live in both soil and water along their life cycle, both aquatic and terrestrial habitats must be protected and restored to conserve them. Many toxins can affect tadpole's and adult's survival as shown by reports of large numbers of developmental abnormalities in frogs [1, 4]. Frog must remain in wet environment to prevent drying out, while toads can tolerate less moisture than frogs; yet, they also seek refuge from the sun by hiding themselves under the shadows of trees, stone, etc [1]. The presence of frog in a particular place indicates that the place remains natural and unpolluted.

Habitat loss can be due to many things, one of which is properties construction. Currently, The $1^{\text {st }}$ Campus of State University of Malang 
(hence, UM), which is located in the heart of Malang District, has been developing rapidly. Thus, it requires the construction of new various facilities to support its huge activities.

According to Zainuri (2012, personal communication), the person in charge of Procurement Services Unit (Unit Layanan Pengadaan/ULP), the development of UM is performed with regards to the green area. This facilities development is conducted by updating the buildings and adding some new constructions. Extensive construction can be destructive even damaging to the habitat of frog, which potentially threats the frog life, if it does not take the environmental impact into careful consideration. This was study aimed to identify the species of frog which survives in UM within seventeen years, particularly the frog species found in 1995.

\section{MATERIALS AND METHODS}

This study was completed within 4 (four) months from March to June 2012. The observation of frog in its habitat was done on March 2012 in four areas around UM in the morning from 6:00 to 10:00 a.m. and in the evening from 06:00 to 09:00 p.m. Morphological observations was carried out by observing the morphological and morphometric characters. Morphological characters include the existence of the limbs, limb size, head shape, body shape, the presence of dorsolateral folds, tympanum, the shape and color of the tympanum, shape the snout, teeth, tongue tip shape, the presence of supraorbital groove, the presence of parietal groove, dorsal skin texture, the color of the dorsal skin, ventral skin texture, ventral skin color, presence of parotoid glands, parotoid gland shape, finger shape, the presence of webbing finger, wide finger webbing the front and hind feet, metatarsal tubercle, sub-articular tubercle, and the habitat discovery of a frog. Morphometric characters include snout vent length (SVL), internarial distance (IN), snout nostril length (SNL), head width (HW), head length (HL), head depth (HD), eye nostril distance (END), eye diameter (ED), interorbital distance (IO), eye to snout distance (ES), upper eyelid width (UEW), tympanum eye length (TEL), tympanum diameter (TD), lower arm and hand length (LAL), forelimb length (FLL), body width $(B W)$, axilla to groin distance (AG), thigh length (TL), tibia length (TBL), hind limb length (HLL), and first toe length (1TL).

\section{RESULTS AND DISCUSSION}

\section{Study of areas}

Based on the morphological characters, four species of frogs were found in UM area, namely, Duttaphrynus melanostictus, Hylarana chalconota. Kaloula baleta, and Polypedates leucomystax (Fig. 1).

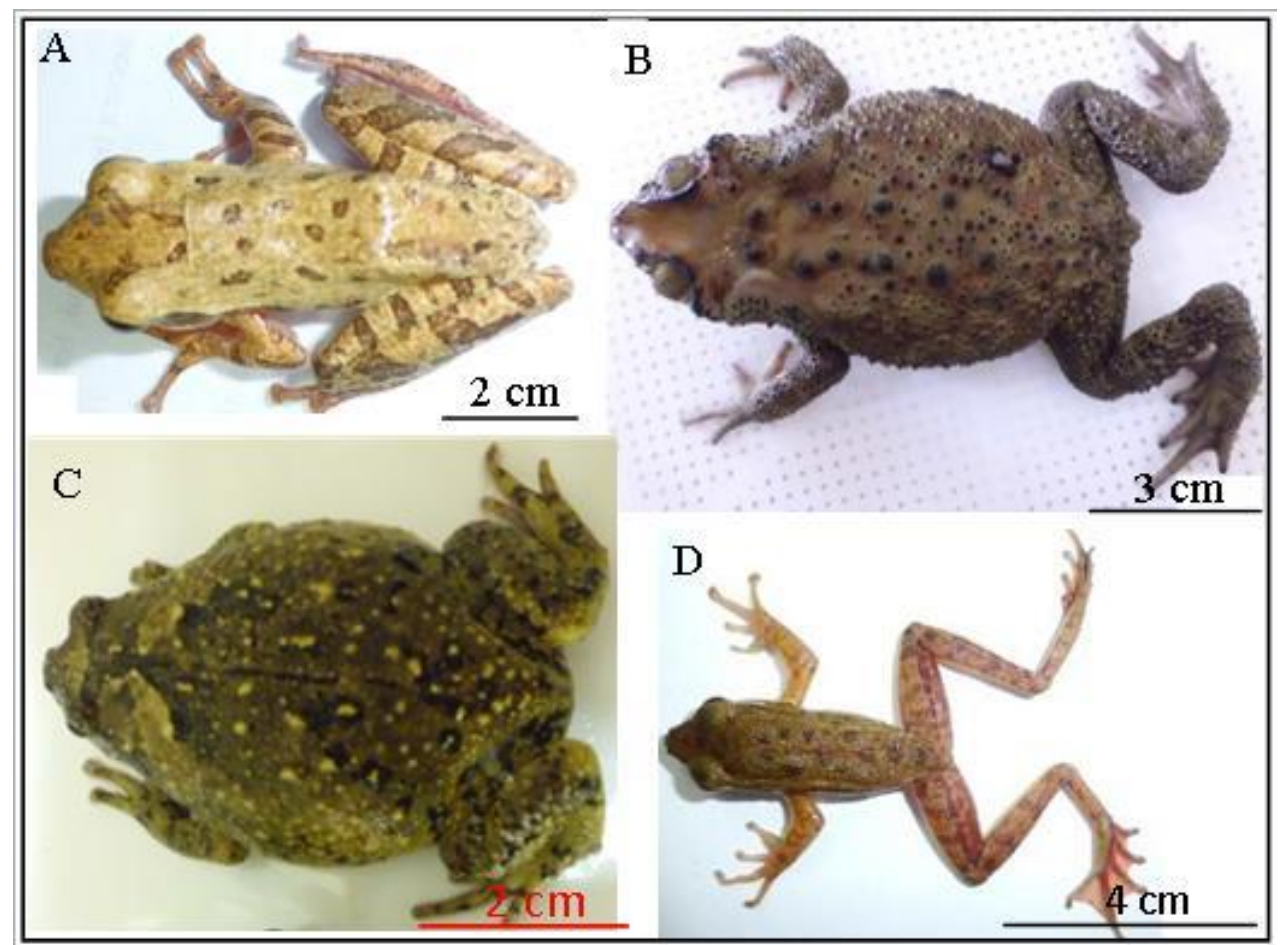

Figure 1. A. P. leucomystax, B. D. melanostictus, C. K. baleata, and D. H. chalconota. 
D. melanostictus is a toad, with the following morphological characters: moderate body size (SVL O : $79 \mathrm{~mm}$ and $q$ : $99 \mathrm{~mm}$ ); black tubercles were spread all over the back; continuous supraorbital and supratympanic ridge; no parietal ridge; half-webbed toes. It was found at all observed area. $H$. chalconota is a frog with the following morphological character; small body size (SVL $\hat{\delta}: 43 \mathrm{~mm}$ ); dark brown tympanum; long and slender legs; fully-webbed toes and fingers; coarsely-granular skin; and found at several ponds in observed area. Kaloula baleta is a brown bullfrog with the following morphological : plump-alike body (SVL O $\mathrm{O}: 51$ $\mathrm{mm}$ and $\mathrm{O}$ : $55 \mathrm{~mm}$ ); short legs; spoon-shaped finger tips, hidden tympanum under the skin; webbed toes (only at the base); and found on puddle which was formed by rain. The last species is $P$. leucomystax, widely known as "stripped tree frog", with the following morphological characters: medium-sized body (SVL ô: $53 \mathrm{~mm}$ ); yellowish-brown, speckled with black spots; six distinct longitudinal stripes (some), nearly fully-webbed toe; and found on the pond with surround (Supplements 1 and 2).

Mashuri reported that in 1995, seven species lived around UM [8]. They were D. melanostictus, $P$. leucomystax, $K$. baleta, Fejervarya cancrivora, Fejervarya limnocharis, Ingerophrynus biporcatus, and Occidoziga lima. However, this study found only three species which were survived since 1995, that is, D. melanostictus, $P$. leucomystax, and $K$. baleta, plus one new species called Rana chalconota. This study also revealed that there were four species which were extinct or lost within 17 years, namely, F. cancrivora, F. limnocharis, I. biporcatus, and O. lima.

The campus' development within the last seventeen years has triggered many environmental changes. The most important change is some natural green areas has turned into parks and buildings. It is likely to cause population declines of frogs and species reduction because habitat destruction is the most pervasive threat $[5,7]$ leading to the decline of amphibian population $[5,6]$.

This result indicates that there is a serious environmental degradation which causes the losing of frog habitats. Further research is needed to study the change in ecological condition in order to save the frog species.

\section{CONCLUSION}

This study reveals four species of frog with the three of them are survivors found in 1995; they are Duttaphrynus melanostictus, Polypedates leucomystax, and Kaloula baleta, plus one new species called Rana chalconota. This study also discloses that there are four species which are extinct, that is, F. cancrivora, $F$. limnocharis, I. biporcatus, and O. lima. This situation shows the decreasing amount of species from 7 to 4 and indicates the environmental degradation within the last 17 years.

\section{ACKNOWLEDGMENTS}

The authors thank to D. T. Iskandar, D. A. Rahayu, and L. Nazar for their assistance and support during this research.

\section{REFERENCES}

1. Bishop DHC (2009) Sustaining america's aquatic biodiversity, frog biodiversity and conservation. Virginia Cooperative Extension. 420-527.

2. Iskandar DT (1998) The amphibians of java and bali. Research and Development Centre for Biology-LIPI. Bogor.

3. Kusrini MD, Endarwin W, Yazid M (2007) Panduan bergambar identifikasi amfibi di jawa barat. Institut Pertanian Bogor. Bogor.

4. Andrew RB, Romansic JM, Kiesecker JM, Hatch AC (2003) Ultraviolet radiation, toxic chemicals and amphibian population decline. Diversity and Distributions. 9: 123-140.

5. Gardner T (2001) Declining amphibian populations: global phenomenon in conservation biology. Animal Biodiversity and Conservation. 24: 25-44.

6. Rodríguez-PrietoI, Fernández-Juricic E (2005) Effect of direct human disturbance on the endemic iberian frog Rana iberica at individual and population levels. Biological Conservation. 123: 19.

7. Young BE, Lips KR, Reaser JK, Ibáñez R, Salas AW, Cedeño JR, Coloma LA, Ron S, Marca EL, Meyer JR, Muñoz A, Bolaños F, Chaves G, Romos D (2002) Population declines and priorities for amphibian conservation in latin america. Conservation Biology. 15: 1213-1223.

8. Mashuri T (1995) Inventarisasi jenis katak di kampus IKIP Malang. Thesis unpublished. Universitas Negeri Malang. Malng. 


\section{Supplement 1}

\begin{tabular}{|c|c|c|c|c|c|}
\hline \multirow[t]{2}{*}{ No } & \multirow[t]{2}{*}{ Morphological Character } & \multicolumn{4}{|c|}{ Species } \\
\hline & & 1 (toad) & 2 (frog) & 3 (striped tree frog) & 5 (bullfrog) \\
\hline 1 & Existence of the limbs & Presence & Presence & Presence & Presence \\
\hline 2 & Pair of limb & 2 pair & 2 pair & 2 pair & 2 pair \\
\hline 3 & Limb size & Short & Long & Long & Short \\
\hline 4 & Clearly of head shape & Clear & Clear & Clear & Clear \\
\hline 5 & Head shape & Big & Not flat & Not flat & Small \\
\hline 6 & Body shape & Solid & Slender & Rather slender & Fat \\
\hline 7 & Dorsolateral folds & Absence & Presence & Absence & Absence \\
\hline 8 & Tympanum & Can seen & Can seen & Can seen & Unseen \\
\hline 9 & Shape of tympanum & Ellipse & Circular & Circular & - \\
\hline 10 & Color of tympanum & Brown & Brown & Brown & - \\
\hline 11 & Shape the snout & Sharp & Sharp & Sharp & Circular \\
\hline 12 & Vomer and maxilla teeth & - & Presence & Presence & - \\
\hline 13 & Tongue tip shape & Uncleaved & Bifida & Bifida & Uncleaved \\
\hline 14 & Supraorbital groove & Presence & Absence & Absence & Absence \\
\hline 15 & Parietal groove & Absence & Absence & Absence & Absence \\
\hline 16 & Dorsal skin texture & Spinous tubercles & Coarsely granular & Smooth & Tubercle \\
\hline 17 & Color of the dorsal skin & Brown & Brown & Brown & Brown \\
\hline 18 & Ventral skin texture & Spinous tubercles & Coarsely granular & Smooth & Smooth \\
\hline 19 & Ventral skin color & White & White & White & White \\
\hline 20 & Presence of parotoid glands & Presence & Absence & Absence & Absence \\
\hline 21 & Parotoid gland shape & Ellipse & - & - & - \\
\hline 22 & Finger shape & Dull & Discus & Enlarged flat & Spoon shaped \\
\hline 23 & $\begin{array}{l}\text { Presence of webbing finger on } \\
\text { forelimb }\end{array}$ & Absence & Absence & Presence & Absence \\
\hline 24 & $\begin{array}{l}\text { Presence of webbing finger on hind } \\
\text { limb }\end{array}$ & Presence & Presence & Presence & Presence \\
\hline 25 & Wide finger webbing the forelimb & - & - & Half webbed & - \\
\hline 26 & Wide finger webbing the hind limb & Half webbed & Fully webbed & Nearly fully webbed & Half webbed \\
\hline 27 & Metatarsal and sub-articular tubercle & Presence & Presence & Presence & Presence \\
\hline 28 & Habitat & Pond, grass, soil & Pond & Tree and pond & Puddle \\
\hline
\end{tabular}




\section{Supplement 2}

\begin{tabular}{|c|c|c|c|c|c|c|c|c|c|}
\hline \multirow[t]{3}{*}{ No. } & \multirow[t]{3}{*}{ Morphometric Character } & \multicolumn{8}{|c|}{ Size (mm) } \\
\hline & & \multicolumn{2}{|c|}{$\begin{array}{l}\text { Species } 1 \\
\text { (toad) }\end{array}$} & \multicolumn{2}{|c|}{$\begin{array}{l}\text { Species } 2 \\
\text { (frog) }\end{array}$} & \multicolumn{2}{|c|}{$\begin{array}{l}\text { Species } 3 \\
\text { (striped tree frog) }\end{array}$} & \multicolumn{2}{|c|}{$\begin{array}{l}\text { Species } 5 \\
\text { (brown bullfrog) }\end{array}$} \\
\hline & & $\hat{0}$ & q & $\hat{\sigma}$ & P & $\hat{0}$ & q & $\hat{0}$ & q \\
\hline 1. & SVL: snout vent length & 79 & 99 & 43 & - & 53 & - & 51 & 55 \\
\hline 2. & IN: internarial distance & 6 & 7 & 30 & - & 4 & - & 4 & 4 \\
\hline 3. & SNL: snout nostril length & 4 & 6 & 1 & - & 2 & - & 1 & 1 \\
\hline 4. & HW: head width & 23 & 32 & 14 & - & 13 & - & 21 & 21 \\
\hline 5. & HL: head length & 22 & 24 & 14 & - & 15 & - & 13 & 18 \\
\hline 6. & HD: head depth & 12 & 18 & 6 & - & 4 & - & 14 & 14 \\
\hline 7. & END: eye nostril distance & 5 & 6 & 4 & - & 5 & - & 3 & 4 \\
\hline 8. & ED: eye diameter & 6 & 6 & 4 & - & 4 & - & 2 & 2 \\
\hline 9. & IO: interorbital distance & 7 & 9 & 3 & - & 5 & - & 5 & 6 \\
\hline 10. & ES: eye to snout distance & 8 & 12 & 7 & - & 6 & - & 4 & 4 \\
\hline 11. & UEW: upper eyelid width & 6 & 8 & 3 & - & 3 & - & 3 & 3 \\
\hline 12. & TEL: tympanum eye length & 3 & 3 & 1 & - & 1 & - & - & - \\
\hline 13. & TD: tympanum diameter & 4 & 6 & 5 & - & 3 & - & - & - \\
\hline 14. & LAL: lower arm and hand length & 36 & 41 & 21 & - & 25 & - & 27 & 28 \\
\hline 15. & FLL: forelimb length & 56 & 59 & 30 & - & 3 & - & 35 & 41 \\
\hline 16. & BW: body width & 50 & 65 & 13 & - & 13 & - & 36 & 36 \\
\hline 17. & AG: axilla to groin distance & 53 & 55 & 19 & - & 25 & - & 3 & 3 \\
\hline 18. & TL: thigh length & 35 & 36 & 23 & - & 17 & - & 21 & 22 \\
\hline 19. & TBL: tibia length & 31 & 33 & 23 & - & 24 & - & 17 & 18 \\
\hline 20. & HLL: hind limb length & 118 & 121 & 76 & - & 7 & - & 67 & 72 \\
\hline 21. & 1TL: first toe length & 5 & 5 & 8 & - & 3 & - & 3 & 4 \\
\hline
\end{tabular}

